\title{
THE LEGITIMACY OF INTERSECTIONS. EXPLORING IDENTITY AND PERSONAL TRUTHS IN LETTY COTTIN-POGREBIN'S DEBORAH, GOLDA, AND ME. BEING FEMALE AND JEWISH IN AMERICA
}

\author{
Ștefana IOSIF \\ Alexandru Ioan Cuza University of Iași
}

\begin{abstract}
Letty Cottin-Pogrebin's autobiography, Deborah, Golda, and Me. Being Female and Jewish in America, immerses the reader into the intersectional world of feminist writing. Pogrebin allows for different genres to cohabitate and create a deeply personal account. At times almost journalistic, at others taking the guise of persuasive activist essays, the work itself mirrors in its shape the theme at its very center: the exploration of identity, done outside of prescribed lines, in the three-dimensionality conferred by multi-faceted sides of the self. As such, Pogrebin brings under one roof former opposites, allowing them to meld together: feminism and religious observance; the personal and the political; motherhood and fatherhood. Identity is not an either/or endeavor, and Pogrebin makes the case for embracing hyphenation and the liberating force of self-definition.
\end{abstract}

Keywords: Feminism, Judaism, autobiography, identity, hyphenation, Jewish-American

In a context that often calls for hyphenation, as the American one undoubtedly does, the struggle for self-definition takes on additional layers. Among those who grappled with their own need to reconcile the multiple facets of the self, we address Letty Cottin-Pogrebin's 1991 autobiographical work, Deborah, Golda, and Me. Being Female and Jewish in America, constructed around the author's own hyphenated identity as a Jewish-American feminist woman and her laborious process of reconciling the multiple sides of the self. As Elaine Showalter notes, "from its inception, women's writing in America has incorporated the 
unconventional along with the predictable, the transgressive and rebellious alongside genteel feminine conformity" (511), thus pushing the canon outside of its constraints and making room for such instances of artistic self-expression as the hybrid autobiography. The autobiography is built on the grounds of her insistence on taking down the artificial dichotomy between the personal and the political, and emphasizing them as never separate, but interwoven and interrelated. The attempt to isolate one dimension of the self from another only comes with detrimental limiting results to the search for one's truth.

Pogrebin's identification as a Jewish woman implies a journey which has gone from what once she, like so many others, had believed to be opposing, mutually exclusive facets of the self, thus dealing in particular with her transformation from a secular to an observant Jewish feminist. As she herself mentions in the introduction,

I have a wandering 'we'... I seem to be caught in a tug of war between women and the Jews... this 'doubleness' is the lot of any woman who leads a hyphenated life... determined by two major aspects of her identity -- femaleness and something else. In my case, the hyphen links a Jew and a feminist... with the gift or burden of double vision and the belief that anti-Semitism and sexism are equivalent evils (Pogrebin xi).

Pogrebin is adamant in her insistence on the thread that historically ties women together. Thus, in bottom-up history there are no unimportant or irrelevant women. The title plays an especially important part in drawing one's attention to this interconnectedness. Deborah and Golda (Meir) act as foremothers for Pogrebin. When faced with the dishearteningly small number of Jewish women models, she decides to "use Deborah and Golda both as historical touchstones and as keynotes to support the book's central themes" (Pogrebin xv). By extrapolation, this can also be felt in her stylistic options. The autobiography is constructed in the form of essays, and organized by major themes, such as family life, religious and political awakenings. As Ruth Brandwein states, "some have criticized this book for jumping from subject to subject, from a beginning autobiography to a critique of patriarchy in Judaism to world affairs", but what quickly becomes poignantly apparent is that "this criticism misses the essential feature of the book: it is feminist in style and structure, as well as in content. Writing in the first person, never objectifying the material, and weaving the personal (micro) together with the political (macro) is what feminism and social work are both all about" (463). In other words, androcentricity is once again rejected in terms of stylistics or clear genre delineations, allowing for a stronger, more personal weave of history, one that rings true and that can be felt as familiar by her readership. As Susan 
Weidman Schneider adeptly points out in her Jewish Women's Archive presentation of Pogrebin, this book offered a

public face on Jewish feminism, rendering the movement less parochial in the eyes of many who might have been self-conscious about their own identification as Jews... her narration of her encounters with religious and communal sexism and her determination to remain attached to a more inclusive Judaism have drawn audiences of disaffected Jewish women all across the country who have welcomed her frank critiques (Schneider n.pag).

From the very beginning of the autobiography, which she intends as a confession, meant to simultaneously set her past in order and to weld together those parts that make up her identity, Pogrebin underscores the multitudes of hyphens that make up the self. Identity is found in the many intersections of human experience. Among them, the one between "I" and "we". As she argues, "the 'I' finds itself in love, work, and pleasure, but it also locates itself within some meaningful group identity - a tribe, a community, a 'we"" (Pogrebin xii). Through belonging to a tribe, one's own self is reflected back at them by the other members, shaped and chiseled by the social identity of the group. This becomes particularly easy to observe in America, a country made up of smaller tribes, who "prefer hyphenation... of the more than 226 million people counted in the last United States census, only 13 million described themselves as 'American'; the rest chose to assert their ethnic ancestry" (Pogrebin xii). Spanning such vast territories, marked by such profound differences, identifying as simply American is felt as insufficient in one's search for self-actualization, as it encompasses too many variables, in spite of the country's perpetual search for uniformity. Being part of a nation of nations encourages and enables a hyphenated self, with individuals situating themselves first within their personal tribe, only subsequently tying it with multiple threads to the larger picture of national identification. Pogrebin dismantles the age-old narrative of the melting pot, asserting simultaneous pledges of loyalty, extending it to include not only national sentiment, but those areas where personal choice reigns supreme. She, thus, relinquishes the pressure of choosing due to external elements, stating that "forced choices are false choices" which intrinsically presupposes a 'both/and' - not 'either/or'- thinking"; as such, when referring to her double loyalty to Judaism and feminism, she is compelled to "interlace ethnicity and gender [or risk being] internally at odds with [herself] and externally vulnerable [as those] with divided loyalties never feel more secure than when we are free to move in two directions" (Pogrebin xvi-xvii). This stance is punctuated throughout the autobiography, as Pogrebin continuously revisits her belonging and her position. As a child, for 
instance, the crumbling of the group she most identified with, her nuclear family, causes her to feel "like a hybrid, unsure of her family, genus, or species... orphaned and alone" (Pogrebin 8), despite still being surrounded by the same people.

Pogrebin's autobiography presents itself as a feminist piece of writing par excellence. The author allows for genres to intersect seamlessly, knitting together instances of intellectual discourse, following the set steps of a persuasive rhetoric, with the profoundly emotional style of detailing personal histories, such as her mother's death, or her uncle's horrifying Holocaust experience. The book mirrors her real life efforts, forcing the reader to accept and embrace a new type of rhetoric. She reiterates the need to grasp the personal in line with the political and the intellectual with the emotional, heralding, along others, an entirely new tradition, both literary, as well as social. Pogrebin explores the hyphenated condition of the American Jewish feminist woman. What had previously been construed as separate, if not downright opposite ideologies, she reunites as facets of the self. One does not need to choose a side to espouse what would be central to their individuality, but rather allow and make provisions for the two to complement each other. Pogrebin's profoundly personal confession accounts for the reclaiming of one's own voice, of images of women with whom one may identify. Deborah, mentioned in the title, is herself a disruption to tradition, as she is the only mentioned female judge, among male counterparts. She functions as the driving force behind effort of mythology (re)creation, implicitly allowing for religious identification with a strong female lead, in a religious system marked by an overwhelming male presence. Pogrebin finds herself at the intersection, positing throughout that, in reality, one's individuality does not lie in prescribed labels, abstractly coined, but in a mélange of multitudes of facets, happily coexisting naturally:

What do I mean by marginal? Neither of my chosen affinity groups is a cultural norm. The human norm is male and the American norm is a white Christian male and as long as Americans are measured against the standards of the white Christian male, both women and Jews will be seen as the Outsider - the Other - and the Jewish woman as the Other twice over (Pogrebin xiii).

A large portion of Pogrebin's personal history revolves around the image of her mother. Despite losing her to ovarian cancer early in life, the figure of the mother is constructed with great dimensions, her death causing a profound gaping hole within the young Letty. In Proustian fashion, the smell of pine-scented cleaning supplies or the aromas of Passover cooking elicit the vivid reminiscence of her mother's ritual for marking the new beginnings brought along by the end 
of winter and the unfolding of spring. With the precision of a metronome, the whole house would shape-shift into a new setting entirely constructed by the mother. Pogrebin's mother is a typical representative the housewife, dedicated to the goal of meeting the expectations that came with that image. The impeccable house was only mirrored by her looking impeccable before the arrival of her husband, "but no matter how lovely my mother looked, he didn't stay home" after eating dinner, but would go out "to attend meetings... a woman in a housedress and a noisy little girl are no match for the lure of a roomful of power and adulation" (Pogrebin 17). In spite of all of her mother's efforts, her father's aloof and distant behavior leads to a loss of "faith in [her] mother's axioms for feminine success" (Pogrebin 17), rules and regulations imposed on the woman, making her lead an existence marked by the approval and acknowledgement of her husband, reducing herself to a performative act, silencing her mind and spirit, and numbing her individual drive with "these bromides" (idem), as Pogrebin calls them, opiates meant to keep the woman confined.

The image of the mother reigns supreme in the realm of Pogrebin's nostalgia. Acting as the perfect foil to the cold intellectual image of the father, Ceil is the guiding light for her daughter's actions, through the sheer power of kindness she exerted. While it cannot be denied that the life paths the two followed were entirely dissimilar, the adult Letty keeps her mother alive within, following a myriad of personal rituals. By abiding by Ceil's Old World superstitions, such as warding off the insidious evil-eye, she maintains the presence of her mother. Through the very power of memory, Ceil's entity resists dissipation, continuing her existence as a force elicited by her daughter. In fact, the legacy of Ceil's life is found in Letty's own life. On the one hand, the image of the ideal life that Ceil wished to cultivate, the typical Brooklyn, suburban housewife, whose main focus is set on domesticity and marriage, is, indeed, discarded by Letty, who, when dealing with matters pragmatically, puts more stock in her mother's ability to build herself up from a poor immigrant, to a career woman, prior to marrying her father, a woman who, through sheer will power, overcomes all inherent limitations, becoming a designer, and thus inspiring her own daughter's professional determination. On the other hand, when setting aside the cool lens of pragmatism in exchange for the softer one of emotion, Letty follows in her mother's footsteps, observing those superstitions which were "a means of imposing order on a chaotic system", when "life was unpredictable and incomprehensible" (Pogrebin 30), and which for Letty meant that "performing these harmless rituals [helped] me keep my mother alive in my mind" (idem). That is particularly true in her Jewish observance, in the personal, intimate version of religiosity that endowed all their Holy Days with deep warmth and magic. As a telling example, she brings to life the wonder of the Hanukkah celebrations, as 
instilled within her by her mother, spreading it all around her, not just in her family, but among Jewish friends whose childhood had been marked by Christmas trees as the epitome of magic; by summoning Ceil's governing spirit, she changes the assimilated, and at times suffocating, tendency, which makes "Christmas... the winter of my discontent" (Pogrebin 106), and exercises "the splendors of the Festival of Lights. I was pleased too that my mother's home-based Judaism passed through me to my children... I only wish she could have lived to see the show" (Pogrebin 110).

Religiosity is associated by the young Letty with her father, as Judaism seemed to take on the deep voice of his reading. For the High Holidays, the father would seemingly reign over the seder table, marking Passover "ennobled in his kipah and kittel... retelling of Israel's liberation from bondage" (Pogrebin 18). Losing her mother, and feeling the deep silencing force of patriarchy while mourning her loss, Letty is alienated from Judaism precisely due to her direct association of all its rituals and rigors with the figure of her distant and emotionally unavailable father. As the years progress, however, her vision shifts, as she understands that quietly hidden underneath the pomp exhibited by her father's voice during holidays was her mother: "my father's virtuosity depended on my mother's labor... the seders I remember with such heartwarming intensity were sanctified by her creation" (Pogrebin 18). It was the mother who made the High Holidays holy, endowing them with a sacred spot in the realm of memories, much more so than her father reciting the scriptures. While he read, she created and brought to life more than a meal, but a spirit of celebration. It becomes apparent that spirituality and tradition are the realm of the mother, and of the Jewish woman in general, allowing for Letty's return to Judaism, and her relentless work in later life to carve out an equal space for women within religion, decidedly undoing millennia of silencing and invalidation, an act described as: “"To cast off thousands of years of Jewish history is risky business,' says Rabbi Marshall Meyer. 'But that doesn't mean that all of the past is right or sacred. Jews have lasted all these years because our ancestors were brave enough to change what wasn't right" (Pogrebin 78). In fact, the mother becomes the very embodiment of a connection with tradition in countless instances, one such example being the only Yiddish song she taught her daughter, despite her belief that "Yiddish was the language of old people and the Old Country - the language parents used to keep secrets from their American born-children, not the vocabulary of my future - but she made an exception for this song, now the anthem of my maternal mythology" (Pogrebin 18). For Letty, particularly as a mature woman, it is through such instances that her connection to her tribe is established. Belonging to Jewry manifested itself in countless ways, one of the threads being this Old World lullaby, which, unbeknownst to her mother, solidifies her own individual identity, by strengthening her adherence to her people. 
Profoundly symbolic is the mother's death and the incomparable impact it has on the life of her fifteen-year-old daughter. Though Pogrebin feels the pangs of loss of what could have been, the celebrations they could have shared, the memories they would have made, had her mother only lived, she is also poignantly aware of the drastic shift her life course took upon losing her mother at such a young age. The dramatic event produces a sudden rupture in a life that would have followed a regular, familiar, albeit banal path - leaving the nest for another in its immediate vicinity, attending a conservative college, only to lead to marriage and children, a life course which her mother would have found entirely appropriate. It does not escape the adult narrator, however, that that would have been a far smaller destiny than the one which began with a tragedy: "her death forced me to live a different life. And since that life has suited me, and I have made gratifying decisions without a mother's advice or counsel, I wonder irreverently, ironically, whether my mother mothered me best by dying" (Pogrebin 20). This visceral admission, which comes in seeming contradiction with the loving tone used by the author in her description of her mother, shocks the reader, and yet it bears undeniable significance. It brings to mind Adrienne Rich's essay "Motherhood and Daughterhood", and her statement that "matrophobia can be seen as a womanly splitting of the self, in the desire to become purged once and for all of our mothers' bondage, to become individuated and free. The mother stands for the victim in ourselves, the unfree woman, the martyr" (118). In other words, through the tragedy of her death, the mother breaks the cycle of bondage to patriarchy and allows her daughter the freedom of self-actualization and self-defining, unencumbered by expectations of wifely standards or even motherhood.

Similarly, Pogrebin takes note of the role mothers bear in the creation of one's own history and, implicitly, mythology of self: "only a mother remembers her children's landmarks as her own. Therefore, losing a mother when you are still a child cuts short your hindsight and historiography. Without my mother's testimony, I know myself almost exclusively through myself. I can only reconstruct that part of the past that I can remember firsthand" (20). Mothers, then, function as physical ties both to an individual past, as well as to a historic past, marked by the ancestry and lineage of motherhood, organically traced to the beginnings of time. Losing one's mother before one becomes a self-standing, selfsupporting individual constitutes a break from or a deterioration of that organic connection, leaving one more fragile, in need of sustained efforts of recovery and reclaiming of the past that eludes personal memory, the collective past of the group. The father is entirely unable to fill in the gaps, despite his purported affection for the child, given by his perpetual absence and distance. This in itself is symbolic as well, as history from the top-down, the one documenting the highest level events, remains a patriarchal realm, infused with the influence of millennia 
of men; it is the bottom-up history, the one with far fewer records, the one marked by orality and tradition, looking at the destinies of everyday individuals that is the realm of the female influence, and of motherhood. This is the history preserved and cherished by the feminine, the one that the young Letty is denied upon her own mother's demise, the valuable contribution of women, whose "experience of oppression enables [them] to reveal aspects of social reality that lie beyond the perspective of the oppressor. In telling the story from the other side, so to speak, feminist scholarship offers a corrective to "normal' scholarship in all fields" (Tirosh--Rothschild 91).

The pervasive institution of patriarchy causes an overlap within the young Letty between her scholarly Jewish father and the religion of her ancestors, as she recognizes her tendency to "[m]erge the Jewish patriarch with patriarchal Judaism" (Pogrebin 45). Despite her own deep understanding of Judaism, her father's rejection and denial of her personhood within the faith pushes the young woman away from institutionalized religiosity, for decades subsequent to the death of her mother, the unifying force, who managed to smooth over the cold father's lacks and oftentimes callous tendencies. To the young Letty, it was poignantly evident that within Judaism "[m]en are 'everyone', women are not" (Pogrebin 49). Quoting from Cynthia Ozick, she underscores a painful truth surrounding the condition of the Jewish woman: "My own synagogue is the only place in the world where I am not named Jew" (Pogrebin 50), as that name is reserved solely to the men of the shul. In her seminal essay, "The Jew Who Wasn't There: Halacha and the Jewish Woman", Rachel Adler poignantly encapsulates the plight of the Jewish woman and her status, relegated by an uncharacteristical insistence on lack of discussion to the confines of Jewish patriarchal stereotypes, "viewed in Jewish law and practice as peripheral Jews", set in a category "exempt from all positive commandments... which for the male Jew, hallow time, hallow his physical being, and inform both his myth and his philosophy... [It] follows that for this category, the characteristic posture of their Judaism is negation, rather than affirmation" (77-78).

Similar to Lerner, who decided to cut ties with Judaism and declared her lack of faith in God upon realizing, before her bat mitzvah, the diminished role and access women have in religious ceremony and decision making (Sklar), Pogrebin suffers a similar, if not more profound disenchantment after her mother's passing. While sitting shiva for her, only nine men are present out of the ten necessary to form a minyan for the kaddish, the communal prayer said for the dead. The young Letty desperately wants to be part of honoring her mother in prayer, begging for her father to include her: "I meant, I want to count. I meant, don't count me out just because I'm a girl... 'For my own mother's Kaddish I can be counted in the minyan'... 'Not allowed!' says my father. He calls the synagogue and asks them to send us a tenth man" (Pogrebin 43). She is thus replaced before 
even being included in the mourning of her parent, her voice reduced to muteness and substituted with that of an entirely unrelated man. The very memory of the mother seems to be forcibly dissolved by the father who gives away her belongings to random family members and acquaintances, not allowing the daughter the right to a physical memento of Ceil, as "he lets them load their arms and pack their cars and take away her history" (Pogrebin 43).

The feeling of being silenced and not taken into account is deepened by the father's disregard of her as an active member of the family, one that would and should offer an opinion and one who would be entitled to a sense of property. The father changes in the daughter's eye from the good "daddy" she thought she could count on, her mother's partner, to an estranged and oftentimes seemingly careless man, who remarries, and pushes his daughter out of his new life. The profound patriarchal system embodied by the paterfamilias strips the daughter of any pretense to equality and enfranchisement, pushing her to the outskirts, with the center inhabited exclusively by men. She is essentially treated as a ward at best, an inconvenient burden at worst, solely due to her gender. In addition to the feelings of abandonment and rage, this in effect causes religion and fatherhood to seem somehow inextricably linked for the young woman. The boundary between the two is virtually nonexistent in her mind:

Both were male-gendered sources of rewarding power. My religion was personified by my Daddy, and I was socially enmeshed in a Jewish world controlled by Jewish men... The creators of historical consciousness and the guardians of privilege were Jewish men like my father, often my father himself... when it mattered to me to be included, he had exercised his masculine right to shut me out. (Pogrebin 45)

The passage is reminiscent of Plaskow's statement regarding the difficult relationship between theology and female experience, particularly in the context of Judaism. For Plaskow, "theology draws on male experience in three ways that are thoroughly interrelated. Specific negative statements about women are not isolated phenomena but are set in a context of androcentric models of God and humanity. Since God is imaged as male, women are put in the position of representing, in their relationships with men, the obedience and humility of the human community before God" (94). As such, the shared sentiment of marginalization is only deepened by her specific circumstances as elicited by her own father, who readily discards her value.

Her father's eagerness to consistently replace the women in his life, both wives, as well as daughters, inherently marks all the ones that came before the present as illegitimate, as marginal pariahs, threatening the order he would impose. Rena, his first daughter, is all but forgotten after his marriage to Ceil; after 
she is reintroduced to the family, a decade and a half later, it is under the pretense that she is a cousin, not his child. After Ceil's death and John's swift remarrying, there is no space in his new life carved out for Letty, whose mere existence is pushed to the outskirts of his universe, both emotionally, as well as financially. Her father's stance is equated with Judaism by the young woman, after being callously replaced in her own mother's mourning ritual, somehow obliterating her status and her claim on her own lineage: "I refused to be an illegitimate child in my own religion. I could not be a ghost in the minyan. If I did not count, I would not stay. I mourned as a daughter, and left Judaism behind" (Pogrebin 50). In their obsessive quest to silence and oust women from the rituals of religion, Jewish patriarchs essentially support and decide " "that the spiritual is political', as Rabbi Julie Greenberg puts it" (Pogrebin 57); through their insistence of equating "everyone" with "every man", mercilessly excluding women from a communion with God, they essentially bring what should have been lofty spirituality down into the confusing shallow murk of secular limitations and deliberations. The goal, then, becomes that women be allowed the same position and status, that they too "develop roles and role models in which righteousness springs from selfactualization, in contrast to the masochistic, self-annihilating model of the postBiblical tzadeket" (R. Adler 82).

Pogrebin delves into the problematic position of women within Judaism in the first part of her autobiography. In these chapters, there is a blend of styles that cannot be ignored. She explores moments of her own past, drawing on her own experience, and yet the narrative is constructed as a manifesto, a collection of essays meant to offer a blend of objective and subjective information. She quotes from numerous other influential Jewish women, such as author Cynthia Ozick, or Zionist figure Henrietta Szold, Orthodox feminist author Blu Greenberg, all of whom share her vision of the necessity of eliminating stifling patriarchal limitations for women in Judaism: "we must demand to be let in, and when refused, we must carry on... put on the pressure, call attention to our plight, and get allies... to petition for our freedom of religion" (Pogrebin 60). As Rachel Adler posits, the Judaism reserved for the Jewish woman revolves around "mitzvot [which] aid and reinforce the life-style of the community and the family, but they do not cultivate the relationship between the individual [woman] and God" (79). In other words, the traditional insistence on the woman and the mother at the heart of Judaism is merely a smoke screen which hides behind it her true status, as enabler and support system for men's ascension to hallowed grounds, she herself being denied true entry of mind and spirit. While the first chapter of the book is categorically and profoundly personal, an intimate prologue delving into the early life of the author, and its effects on her as an adult, once the change is made to "Deborah", the narrative is no longer simply that of the search and ordering of the past self, an incursion in memory, but an active speech meant to 
persuade and exact change. What is seen as a departure from autobiographical writing is in fact a reimagining thereof. Pogrebin blends memorialistic writing with activist writing in an attempt to clarify the personal impact and implication activism and political stance have on the individual.

Women are, thus, departing from the sterile grounds of patriarchy and (re)forming spirituality on their own terms, with new definitions. Creating spaces for themselves where they can explore their religiosity, these havurot offer an entirely new experience for those who felt diminished by orthodoxy. As Pogrebin states, "there is nothing quite like the feeling of community created by women for women in a Jewish context... inevitably I get seduced by the sweetness of sisterhood" (61). These new forms of congregating and worshipping are also constructed as hybrids - there is no perceived border between matters of the spirit, of religion, or of social activism and involvement "in the context of class, race, sexuality, ethics, and ethnicity" (Pogrebin 61), as they do away with artificial divisions and allow for a melding of all spheres of life, so that even when making the religious pilgrimage to Rachel's Tomb, reclaiming and resurfacing female midrash, feminists "ask God to fulfill their prayers - which are as often political as personal" (Pogrebin 76). This insistence on removing the metaphorical mehitzahs from their own lives reinforces the relevance of allowing all facets that make up the self, religious, political, or personal, to simultaneously cohabitate, and enable one to lead their entire existence three-dimensionally, fully rounded, away from the flatness of dedicated tunnel vision.

The mark of patriarchy is so profound, that extraordinary efforts are required to simply accommodate the Jewish woman within the practices of Judaism. While some extent of alienation mars the spirituality particularly of observant Jewish feminists, Pogrebin finds a way to circumvent it in her envisioned version of Judaism, a version meant to accommodate the many, and oftentimes contradictory rituals and traditions. She suddenly finds a way to reconcile herself to religion and rituals that had hitherto been associated with her estranged father, whose hurtful actions had pushed her outside the scope of her ancestral faith. As a child, she would not join her mother in her preparations for the High Holy Days, but would be granted what she saw as the favor of her own patriarch, accompanying the father to the shul, davening with him during the services, immersed more fully than women would be in these mystical practices. She states that "[what] I wished for was not a boy's sex but his tallit and tefillin and his significance in Jewish life" (Pogrebin 84), as her psyche dealt with the contradictory path splaying in front of her - on the one hand, being her father's protégée, and the assumed heir of his intellect and wisdom, and on the other, limited by her own gender to assume nothing more after becoming a woman than 
the traditional roles of wife and mother, isolated from the true life of Jewish spirituality, falling into the patriarchal mold of womanhood.

Despite her disillusionment with the patriarchal foundation of Judaism, Pogrebin maintains a connection by still observing the High Holidays of Judaism, as a reminder of her mother, whom she associates with the rituals and the warmth of the Holy Days. As she mentions, "I wasn't going to let my alienation from my father's religious institutions cut me off from the rituals... associated with my mother and the home-based Judaism in which my heritage seemed... most real" (Pogrebin 13). This point of view has been espoused, as Pogrebin herself lists in her second chapter, by countless women who felt alienated by the institutional valency of religion or spirituality, rather than the ritualistic one. Tamar Rudavsky makes a very astute point when she argues in her essay, "Feminism and Modern Jewish Philosophy", that the main issue so many women take, like Pogrebin, is the forced silencing. Women are not allowed a presence or a voice within organized religion and "feminist theologians have maintained that Western religious traditions have systematically excluded women's voices; that religious institutions have been predominantly male-oriented and reflect male concerns and priorities; and that many canonical religious texts, written almost exclusively by men, contain misogynist statements" (Rudavsky 324). This androcentricity spreads all across religious and philosophical thought, as Judith Plaskow would argue, as well: "Men are the actors in religious and communal life because they are the normative Jews. Women are 'other' than the norm; we are less than fully human" (qtd in Rudavsky 324). The implication would seem to be then that women are excluded from Judaism in its entirety, thus calling for a secession of women from Judaism.

This polarization of the two elements, gender and religion, leads to feminist struggles to offer a reconciliatory hyphen between the two. In other words, their aim is to create a bridge that would not only occasionally unite them, but would gradually bring them together, until the union is permanent and entirely seamless. What allows for this is the fact that despite its undoubtedly patriarchal undertones, Judaism makes provisions within its philosophical discourse that allow for a progressive approach, one that would enable the seedlings of feminist thought to take root. Pogrebin gives the example of the Kaddish once again, as the most commonly quoted traumatic denial suffered by women within Judaism. She mentions the fact that "under Jewish law, children are obligated to say Kaddish for their deceased parents", but the obligation through custom is only applied to sons, and despite the lack of prohibition by law for daughters to also recite the prayer, custom once again imposes an unwritten law on them, effectively pushing them "out of sight behind the mehitzah... numbed and nullified" (Pogrebin 51). The divine law is, therefore, undermined by customary habits which "fly in the face of far more fundamental mitzvoth - instructions to pursue justice, love 
mercy, care for the weak, show empathy for the stranger, and practice loving kindness toward all human beings. This glorious ethical mandate... is breached in the name of the small, base custom of controlling women's spiritual autonomy... by men who consider themselves holy" (Pogrebin 55). As Rachel Adler concludes, "[for] too many centuries, the Jewish woman has been a golem, created by Jewish society. She cooked and bore and did her master's will, and when her tasks were done, the Divine Name was removed from her mouth. It is time for the golem to demand a soul" (82).

It is no surprise that Judith Plaskow, the first female Jewish theologian, is present in most of the literature related to feminist Judaism, and Pogrebin's autobiography is no exception. Plaskow offered Pogrebin the logic that helped rekindle her covenant with religion. Pogrebin partakes of the "yeah, yeah experience" as described by Plaskow in her seminal work, The Coming of Lilith: it is a "double recognition... the process through which we become sisters... a different way of thinking from our usual 'yes, but' reasoning, which is inherently nondialogical" (46-48). Like Plaskow, Pogrebin argues against the notion of the finality of the Torah, which despite its sanctity is only a portion of what Judaism and the Jewish experience are and will be, precisely due to its general omission of women. Without their experience recorded, one cannot reach fullness. Given the universality and wisdom that the Torah offers, it allows for a new process of midrash-making, one that would be inclusive of women, not simply as afterthought characters, but as central to faith. As such, "the Judaism defined by the rabbis of the Talmud is only one interpretation of Judaism; alternative interpretations can have equal validity. It is our task, Plaskow says, to 'reinterpret the past to meet the needs of a radically different present"' (qtd in Pogrebin 67). This dismantles the androcentricity common to religious expression as a form of human error, and allows for the perfectibility of a living Judaism, one that evolves with the ages in its specificities, all the while maintaining its core essence. As such, Pogrebin's Judaism "is a Judaism of compromise but not complacency... I see no other way to be a Jew whose spiritual life is in tune with her integrity as a woman. From the menu of classic and innovative Jewish observances, I have chosen the rituals that nourish me best. It's not a glatt kosher meal, but it is a balanced diet and no one is turned away from the table" (Pogrebin 81).

It would inevitably take numerous further steps for the healing process to engulf her previous deracination and allow for her own vision of Judaism to take roots. There were numerous skirmishes within her divided psyche between the different sides of her: her feminist head fought against her Jewish heart, as she herself states. Loyalty to one meant discarding the other, many times with no other result than her own loss and pain. While attending the Jewish Feminist Conference in 1988, she does not join the others to the Western Wall for the historic first 
reading of the Torah on the women's side of the kotel, after immense efforts from the Women of the Wall group to assert their right to pray, such as Francine Klagsburn, or Norma Joseph, whose epiphanic and transcendent accounts she quotes. Instead, she, having vowed never to attend a segregated service, "missed this transcendent service at the Wall - a great loss. By allowing rebellion to become a more compelling motivation than feminist solidarity, I cheated myself; I became the casualty of my own stored-up rage" (Pogrebin 71). This constitutes one more instance when the pressure of choosing either-or results in a stunted individual experience, rather than an uplifting instance of reaffirming faith. It becomes apparent once again that regardless of how seemingly contradictory, the different sides of the self must be allowed to maintain an organic, natural sequence, a fragile balancing act which sways to one side, then to the next, without dismantling one another, but rather reinforcing and redeeming each other.

When exploring those things which are most deeply rooted in her experience, Pogrebin recognizes not only the feminist reappropriation and reform of Judaism, but also the traditional prayers, the words seeped in patriarchy, but which resonate within her loudest: "If I don't remember the old songs and pass them to my children, the songs will die with me. But, say the makers of new sounds, the old lyrics leave women out. I know, I say, but women sang them. My foremothers sang them. I hear their echoes" (Pogrebin 79). To simply discard them would inherently mean a departure from her own roots and truth. As such, she makes allowances for their coexistence. As Deidre Butler emphasizes in her essay, "Disturbing Boundaries: Developing Jewish Feminist Ethics with Buber, Levinas and Fackenheim", it is not enough to think of Jewish feminist reactions to rabbinical writing as a separate layer, added to the pot, but rather "a more compelling account of Jewish feminist ethics emerges as we move from an additive description to a more complex relation in highlighting how feminist theory and methodology subtly and radically reframes and reorients the subject and object of Jewish ethics" (327), thus supporting Pogrebin's stance of refusing to discard what was marked by patriarchy, opting to reclaim and repurpose it in her inclusive feminist framework. In a profoundly symbolic coincidence, she spends thirteen years as cantor, seemingly undergoing another type of Bat Mitzvah, as "the first coming-of-age tested my mastery of dogma and absolutes; the second developed my capacity to synthesize and question" (Pogrebin 93), once again erasing yet another harsh border, with her female voice carrying the chants of holy prayers to a God so used to men's confessions. 
Ştefana IOSIF

\section{Works Cited}

Adler, Rachel. "The Jew Who Wasn't There: Halacha and the Jewish Woman” 1973. Jewish Women's Archive. <https://jwa.org/media/jew-who-wasnt-there-halachaand-jewish-woman>.

Brandwein, Ruth. "Deborah, Golda and Me. By Letty Cottin Pogrebin". Affilia Volume 8 issue 4 Book Reviews - New York Doubleday. Anchor Books, 1992. Print.

Butler, Deidre. "Disturbing Boundaries: Developing Jewish Feminist Ethics With Buber, Levinas And Fackenheim.” Journal of Modern Jewish Studies, vol. 10, no. 3, 2011, pp. 325-350.

Plaskow, Judith. The Coming of Lilith - Essays on Feminism, Judaism and Sexual Ethics, 1972-2003. Boston: Beacon Press, 2005.

Pogrebin, Letty Cottin. Deborah, Golda and Me. Being Female and Jewish in America. New York City: Anchor Books, 1992.

Rich, Adriene. "Motherhood and Daughterhood". Essential Essays. Culture, Politics, and the Art of Poetry. ed. Sandra M. Gilbert. Norton\&Company, 2018.

Rothschild, Hava Tirosh. ""Dare To Know": Feminism and the Discipline of Jewish Philosophy". Feminist Perspectives on Jewish Studies, eds Lynn Davidman and Shelly Tenenbaum. Yale University Press, 1994.

Rudavsky, Tamar. "Feminism and Modern Jewish Philosophy." The Cambridge Companion to Modern Jewish Philosophy, ed. Michael L. Morgan and Peter Eli Gordon, Cambridge University Press, Cambridge, 2007, pp. 324-348. Cambridge Companions to Religion.

Schneider, Susan Weidman. "Letty Cottin Pogrebin." Jewish Women: A Comprehensive Historical Encyclopedia. 20 March 2009. Jewish Women's Archive. (Viewed on August 31, 2019) < https://jwa.org/encyclopedia/article/pogrebin-lettycottin>.

Showalter, Elaine. A Jury of Her Peers: American Women Writers from Anne Bradstreet to Annie Proulx. Vintage Books, 2010.

Sklar, Kathryn Kish. "Gerda Lerner." Jewish Women: A Comprehensive Historical Encyclopedia. 27 February 2009. Jewish Women's Archive. (Viewed on August $31,2019)<$ https://jwa.org/encyclopedia/article/lerner-gerda $>$.

\section{BIONOTE}

ȘTEFANA IOSIF has just defended her PhD thesis at the Doctoral School of Philological Studies of Alexandru Ioan Cuza University of Iași, having conducted research focused on Jewish-American autobiographical writings. Additionally, she is an associate teaching assistant at the university level, with classes varying from Interculturality and American Political Institutions, to Grammar and Medical Translations. She is an avid feminist and humanist, taking a special interest in social and cultural issues. Her ancestry is mostly of Romanian descent, and one of her aspirations is to trace her lineage as far back as documents would allow.

E-mail:stefana.isf@gmail.com 
